\title{
Article
}

http://dx.doi.org/10.11646/phytotaxa.172.3.5

\section{Echeveria cerrograndensis (Crassulaceae) a new species from eastern calcareous Sierra de Manantlán, Colima, Mexico}

\author{
GREGORIO NIEVES-HERNÁNDEZ ${ }^{1}$, J.ANTONIO VÁZQUEZ-GARCÍA ${ }^{1}$, MIGUEL ÁNGEL MUÑIZ-CASTRO $^{1,3}$, \\ \& MIGUEL CHÁZARO-BASÁÑEZ ${ }^{2}$ \\ ${ }^{1}$ Herbario IBUG, Instituto de Botánica, Departamento de Botánica y Zoología, \\ Universidad de Guadalajara-CUCBA, Zapopan, Jalisco, México \\ ${ }^{2}$ Laboratorio de Biogeografia, Departamento de Geografia, \\ Universidad de Guadalajara-CUCSH, Guadalajara, Jalisco, México \\ ${ }^{3}$ E-mail:miguelmunizcastro@gmail.com,mca44083@cucba.udg.mx
}

\begin{abstract}
Echeveria cerrograndensis, a new species from eastern Sierra de Manantlán, in the Jalisco-Colima border, Western Mexico, is described and illustrated. This species belongs to series Gibbiflorae, it is morphologically related to E. fulgens but it differs from the latter in having smaller habit, margin straight to slightly undulate; glaucous to pale green or reddish leaves; lower number of flowers per branch and lower total number of flowers; shorter inflorescences, none bicolored corolla, and dark red thecae and nectaries. A key for the species of the E. fulgens complex is provided.
\end{abstract}

Key words: Echeveria fulgens, endemic, Tolimán, rock flower (“flor de piedra”)

\section{Resumen}

Echeveria cerrograndensis se describe e ilustra como especie nueva de la porción oriental de la Sierra de Manantlán, Jalisco-Colima, México. Esta especie pertenece a la serie Gibbiflorae, se asemeja a E. fulgens, pero difiere de esta última en su hábito más pequeño, hojas glaucas a verde pálido o rojizas con margen recto a ligeramente ondulado, menor número de flores por rama, menor número total de flores, inflorescencias más cortas, corola de un solo color, y en sus tecas y nectarios de color rojo oscuro. Se incluye un clave de identificación para las especies del complejo E. fulgens.

\section{Introduction}

Echeveria DC. (Candolle 1828: 401) comprises some 140 known species, and 95\% of these are found in Mexico, the center of diversity and endemism of the genus (Uhl 1992, Thiede 1995, Meyrán-García \& López-Chávez 2003, Etter \& Kristen 2013). There are nearly 20 species of Echeveria in western Mexico, including the one described here, 15 of which occur in the State of Jalisco, Mexico (Pilbeam 2008), mostly distributed in temperate mountainous rocky areas, with four of them strictly occurring in tropical forests and only two of them inhabiting on calcareous rocks: 1) the ivory-white flowered Echeveria yalmanantlanensis A. Vázquez \& Cházaro (Vázquez-García et al. 2013) and 2) the pink flowered Echeveria here described here as new. As expected by Uhl (2002) and Pilbeam (2008), several new species have been described recently out of the Echeveria fulgens Lem. (Lemaire 1845: 8) complex, including E. roseiflora J. Reyes \& O. González (Reyes-Santiago \& González-Zorzano 2010: 22), E. perezcalixii Jimeno-Sevilla \& P.Carrillo (Jimeno-Sevilla \& Carrillo-Reyes 2010: 303), and E. purhepecha I. García (García-Ruiz 2011: 63) and E. munizii Padilla Lepe \& A.Vázquez (Vázquez-García et al., in press).

Here we describe Echeveria cerrograndensis, another new species out of the E. fulgens complex, a rupicolous species in karstic topography of the Cerro Grande massif in the Sierra de Manantlán Biosphere Reserve, Jalisco-Colima, Mexico, a species that despite its abundance remained unnoticed to many botanists undertaking intensive explorations in the natural area (Vázquez et al. 1995). Echeveria cerrograndensis was first discovered in 2002, when Miguel Cházaro, Ignacio Contreras and Antonio Machuca visited Cerro Grande, Minatitlán, Colima, México. Living specimens were obtained on a second trip in July 2004, that later bloomed at home of Antonio Vázquez in January 19, 2005. 


\section{Key to species of the Echeveria fulgens complex}

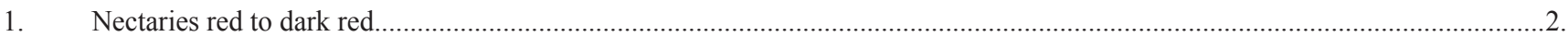

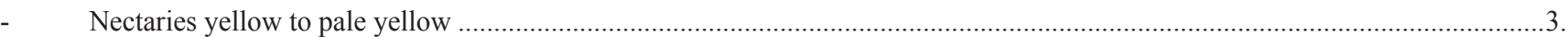

2. Stems not evident; leaves $6-10 \times 3.5-5.5 \mathrm{~cm}$, margin crenulated and reddish; floral stems $2-3,50-54 \mathrm{~cm}$, total number of flowers $(12-) 18-20$, nectaries red ................................................................................................................................ roseiflora Stems $2-5 \mathrm{~cm}$; leaves $(3-) 4-6 \times 2.5-3.5 \mathrm{~cm}$, margin straight and pinkish; floral stems $1-2,11-22(-35) \mathrm{cm}$, total number of flowers 4-11; nectaries dark red ............................................................................................................... E. cerrograndensis

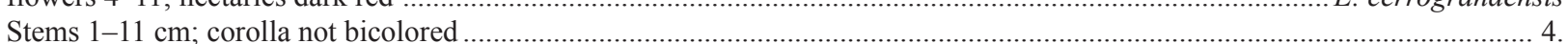

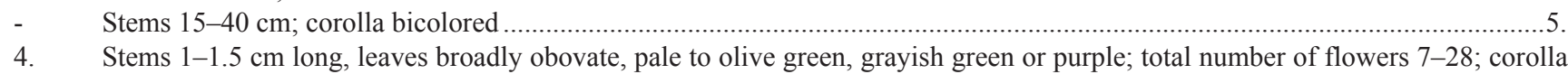
orange pinkish to pink .................................................................................................................................. perezcalixii

Stems $8-11 \mathrm{~cm}$ long, leaves oblong-obovate, pale to dark green; total number of flowers $5-7$; corolla scarlet red to coral red........

5. Bracteoles absent; leaves green yellowish, somewhat glaucous, to dark red, the margin undulated reddish, not hyaline; inflorescence 50-90 cm; total number of flowers ca. 20-24, flowers per branch 12 or more, pedicels 2-6 mm; corolla $12-15 \mathrm{~cm}$ long.

E. fulgens Bracteoles present; leaves green or olive to brownish green, the margin straight green, hyaline; inflorescence $30-40$, total number of flowers 10-11, flowers per branch (1-)3-5, pedicels 7-8 $\mathrm{mm}$; corolla $10-11 \mathrm{~cm} \mathrm{long.}$ E. munizii (in press)

\section{Acknowledgements}

To Daniel Barba, for his excellent art drawings. To Ignacio (Nacho) Contreras, Antonio Machuca, Julia Etter, Raúl López Velázquez and Rodolfo (Roy) Sánchez, field companions and collaborators in trips to Cerro Grande. To Federico Luebert and an anonymous reviewer for their valuable suggestions that improved the manuscript.

\section{References}

Berger, A. (1930) Crassulaceae. In: A. Engler \& K. Prantl (eds.), Die natürlichen Pflanzenfamilien 18A (2nd ed.). W.Engelmann, Leipzig, pp. 352-483.

Candolle, A.P. (1828) Crassulaceae. In: A. P. de Candolle, A. P. \& de Candolle A. L. P. P. (eds.), Prodromus Systematis Naturalis Regni Vegetabilis 3. Treuttel \& Würtz, Paris, pp. 382-414.

http://dx.doi.org/10.5962/bhl.title.286

Carrillo-Reyes, P., Sosa, V. \& Mort, M.E. (2009) Molecular phylogeny of the Acre clade (Crassulaceae): Dealing with the lack of definitions for Echeveria and Sedum. Molecular Phylogenetics and Evolution 53: 267-276.

http://dx.doi.org/10.1016/j.ympev.2009.05.022

Etter, J. \& Kristen, M. (2013) Crassulaceae. Data base. Available from: http://www.crassulaceae.com/botanik/botcrassulaceae_en.asp (accessed: 05 February 2013).

García-Ruiz, I. (2011) Nueva especie de Echeveria del centro-occidente de Michoacán, México. Revista Mexicana de Biodiversidad 82: $63-67$.

Iltis, H.H., González-Gallegos, J.G., Cochrane, T.S., \& Vázquez-García, J.A. (2012) A new species and a new subspecies of Salvia (Lamiaceae) from Jalisco and Michoacán, Mexico. Brittonia 64: 343-352.

http://dx.doi.org/10.1007/s12228-012-9237-1

Jimeno-Sevilla, H.D. \& Carrillo-Reyes, P. (2010) Echeveria perezcalixii, una especie nueva del occidente de México. Brittonia 62: 303308.

http://dx.doi.org/10.1007/s12228-010-9137-1

Kimnach, M. (2003) Echeveria. In: Eggli, U. (ed.), Illustrated Handbook of Succulent Plants: Crassulaceae. Springer, Berlin, pp.103128.

Lemaire, A.C. (1845) Echeveria fulgens: Crassulacées \& Obilicees. Hortus Vanhoutteanus 1: 8.

Meyrán-García, J. \& López-Chávez, L. (2003) Las Crasuláceas de México. Sociedad Mexicana de Cactología, A.C. México, D.F., 234 pp.

Moran, R. (1974) Division of genus Echeveria into series. In: Jacobsen, H. (ed.), Lexicon on succulent plants. Blandford Prees, London, pp. 184-186.

Pilbeam, J. (2008) The genus Echeveria. The British Cactus \& Succulent Society, Essex, 333 pp. 
Reyes-Santiago, J. \& González-Zorzano, O. (2010) Echeveria roseiflora (Crassulaceae) una nueva especie para el estado de Jalisco, México. Cactáceas y Suculentas Mexicanas. 55: 19-26.

Thiede, J. (1995) Quantitative phytogeography, species richness, and evolution of American Crassulaceae. In: Hart, H. \& Eggli, U. (eds.), Evolution and systematics of the Crassulaceae. Backhuys Publishers, Leiden, pp. 89-123.

Uhl, C.H. (1992) Polyploidy, dysploidy and chromsome pairing in Echeveria (Crassulaceae) and its hybrids. American Journal of Botany 79: 556-566.

http://dx.doi.org/10.2307/2444868

Uhl, C.H. (2002) Chromosomes and hybrids of Echeveria (Crassulaceae). VII. Series Gibbiflorae (Baker) Berger. Haseltonia 9: 121145.

http://dx.doi.org/10.2985/1070-0048(2005)11[138:cahoed]2.0.co;2

Unger G. (1974) Ferocactus reppenhagenii Unger spec. nov. Kakteen und Andere Sukkulenten 25: 50-54.

Vázquez-García, J.A., Cuevas-G., R., Cochrane, T. S., Iltis, H.H., Santana-M., F.J. \& Guzmán-H., L. (1995) Flora de Manantlán. Sida Botanical Miscellany 13: 1-312.

Vázquez-García, J.A., Jimeno-S., D., Cuevas-Guzmán, R., Cházaro-B., M. \& Muñiz-Castro, M.A. (2013) Echeveria yalmanantlanensis (Crassulaceae) a new species from Cerro Grande, Sierra de Manantlán, western Mexico. Brittonia 65: 273-279.

http://dx.doi.org/10.1007/s12228-012-9274-9

Vázquez-García, J.A. Nieves-Hernández, G., Padilla-Lepe, J., Nuño-Rubio, A.T. \& Cházaro-Basáñez, M. (2014, in press). Echeveria munizii (Crassulaceae) an epiphytic new species in tropical gallery forest at Volcán de Colima, Mexico. Phytotaxa. 